\title{
Psychological Duty and Therapeutic Relationship: The Point of View of Attended Clients
}

\author{
Emanuel Meireles Vieira1,2, Gabriela Di Paula Dias Ribeiro1, \\ Bianca Nascimento de Souza1, Jacqueline de Oliveira Moreira ${ }^{3}$, \\ Paula Affonso de Oliveira ${ }^{1}$ \\ ${ }^{1}$ Department of Psychology, Universidade Federal do Pará, Belém, Brazil \\ ${ }^{2}$ Post-Graduation Program of Psychology, Universidade Federal de Minas Gerais, Belo Horizonte, Brazil \\ ${ }^{3}$ Post-Graduation Program of Psychology, Pontifícia Universidade Católica de Minas Gerais, \\ Belo Horizonte, Brazil \\ Email: emanuel.meireles@gmail.com, gabriela.ribeiro.ufpa@gmail.com, bianasso@hotmail.com, \\ jackdrawin@yahoo.com.br, paulaoliveira.psi@gmail.com
}

Received 25 March 2014; revised 19 April 2014; accepted 16 May 2014

Copyright (C) 2014 by authors and Scientific Research Publishing Inc.

This work is licensed under the Creative Commons Attribution International License (CC BY). http://creativecommons.org/licenses/by/4.0/

(c) (i)

\section{Abstract}

This work aims to examine what the clients cared for in a service of psychological duty, guided by a person-centered therapy, and consider meaningful as for the way the psychologist on duty relates to them. For that, semi-structured interviews were done with 5 clients cared for by this service, and the phenomenological method of research was used to analyze the interviews. Thus, we reached six analysis categories: 1) feel heard; 2) interest from the psychologist on duty; 3) feel welcome; 4) confidence; 5) unlimited time; 6 ) self-knowledge. Through the analysis of all the categories, it was possible to reach the conclusion that, even in a service that is so distinct from the psychotherapy as the duty service is, it is possible for the client to realize those that, according to Rogers, would be the necessary and sufficient conditions for the change of personality. Besides, it was possible to perceive the relevance of the quality of the presence of the psychologist on duty in the established relationship with the interviewed clients.

\section{Keywords}

Psychological Duty, Therapeutic Relationship, Point of View of the Client, Person-Centered Approach, Humanistic Psychology 


\section{Introduction}

The therapeutic relationship and its qualities are a recurrent theme in any theoretical focus adopted in Psychology. In 1999, for example, the American Psychological Association (APA) created a task-force to research characteristics of effective therapeutic relationships and concluded that the techniques employed by the therapist are not determinant in this process, but the quality of the relationship that he/she establishes with his/her client (Norcross, 2001).

When it comes to the Person-centered Approach (PCA), it is possible to say with confidence that Carl Rogers, its creator, looked into this topic all throughout his life in the most diverse ranges of human relations (Moreira, 2010). The theorization about the facilitating attitudes in the therapeutic relationship (unconditional positive regard, congruence and empathetic comprehension) constitutes an example of the Rogerian preoccupation with the quality of the relationship that is established between therapist and client. Those theorizations are, nowadays, study objects of different theorists (Bohart \& Byok, 2005; Kirschenbaum \& Jourdan, 2005; Moreira, 2007, 2009; Myers, 2000; Schnellbacher \& Leijssen, 2009).

In agreement with our argumentation, we can mention the reflection of Rogers (1957/1992) about the theme of the necessary and sufficient conditions for the therapeutic personality change, which are: that a minimum relationship between two people is established, named "psychological contact" by Rogers; that the client "is in a state of incongruence, being vulnerable or anxious" (Rogers, 1957/1992: p. 827); that the therapist "is congruent or integrated in the relationship” (Rogers, 1957/1992: p. 827); that the therapist experiences unconditional positive regard to the client and an empathetic comprehension of his internal frame of reference, as well as make an effort to communicate this comprehension; and also that the communication of the empathy and the unconditional positive regard experienced by the therapist be carried out, at least minimally.

These postulates, with some variations, show to be useful in the most diverse ranges in which PCA is used as a methodological propose, adjusting themselves to contexts that are not only those of psycotherapy (Battaglia, 2009; Justo, 2002; Mahfoud, 1999; Mozena, 2009; Rogers, 1977/2001; Tassinari, Cordeiro, \& Durange, 2013; Vieira \& Ximenes, 2011). Rogers (1957/1992) predicted that "psychotherapy is not the only situation aimed at constructive personality change” (p. 832).

This way, the principles that guide the psychotherapeutic relationship as we traditionally know in the PCA can be probed and adjusted to other contexts. One of these contexts is the psychology duty, practice developed from 1969 in the University of São Paulo, Brazil (Almeida, 2009; Breschigliari \& Rocha, 2009; Mahfoud, 2013; Perches, 2009; De Souza \& De Souza, 2011), founded in the Person-centered Approach (PCA) and inspired in the walk-in clinics from the United States. The walk-in clinics, according to Mozena (2009), are characterized for being available when other services are closed, being in a location of easy access and for not requiring a previous appointed schedule with the health professional so that, according to Mozena (2009), they promote “...the access to the primary healthcare, mainly to people who have difficulty to have access to other health institutions" (p. 45).

According to Mahfoud (1987: p. 75),

...the expression "duty" is associated to a kind of service performed by professionals that keep themselves available to any person who needs them, in periods of time previously determined and non-stop. From the point of view of the institution, the duty service requires a systematization of the offered service. From the professional, this system requires an availability to the hypothesis that the meeting with the client becomes unique. And, also, from the perspective of the client, it means a reference point for any moment of need.

The psychology duty is envisaged, then, as a diverse service from the traditional psychotherapy (Dutra, 2004). In this model of attendance we can highlight the non-requirement of a sequence of attendances and the availability of the on duty psychologist to the client at the closest time possible that the need of help arises. The quantity of sessions offered in the psychology duty varies from one to four (Vieira, 2012), according to the case to be attended, so that the attendance can end in itself or the patient can be referred to either another service modality of Psychology or not. It is in this sense that Perches (2009) states that the end of the process of the psychological duty is "...the clarification of the person who looked for this kind of service as for his/her complaint, problem and to what was given new meaning, changing, or even widening the perception of the situation ...in which he/she was in” (p. 52). As it can be observed, the service is regulated according to the demand from the people and widens their access to a service of psychological attendance (Cury \& Ramos, 2009; Mozena, 2009). 
In the psychological duty, it is aimed to establish a relationship in which the client feels genuinely respected and understood by the psychologist on duty and, as a consequence, “...by feeling respected and understood in his peculiar way of giving meaning to the personal problematic, he can rebuild his autonomy” (Cury \& Ramos, 2009: p. 135). This way, the psychological duty does not come down to a cathartic moment, instead, it is the affirmation of autonomy of those who seek for help and the possibility of one only meeting be indeed meaningful in a moment of crisis.

According to Perches (2009), the following are principles that guide the psychological duty: a wider comprehension of the service; the widening of demands to be attended, once it is not centered in the problem, but in the person who seeks help; an attempt to avoid the chronicity of a psychological demand, since the person is cared for at the moment he/she feels the need to. For that, it is demanded from the therapist the following qualities: opening to the unpredictable; a high level of empathy capacity; the development of a true interest for the client; flexibility as for the pre-established models of therapeutic relation; and the awareness that the meeting can be (and many times it is) the only one (Mahfoud, 2013; Mozena, 2009; Perches, 2009).

Even though there are other psychological approaches that support such way of acting, PCA appears in highlight in this aspect. There are many researches done in the last few years that use it as a theoretic-methodological referential (De Souza \& De Souza, 2011). This way, the conditions described by Rogers (1957/1992) found the practices of many psychological duty services in Brazil, since the birth of this kind of service (Breschigliari \& Rocha, 2009).

Having as a basis the idea that PCA and its theory of the human relationships being possible justifications for the acting in psychological duty, we admit as true the conditions that Rogers (1957/1992) establishes as necessary and sufficient for the therapeutic change of personality. Especially to what concerns the perception of the client in relation to the attitudes of the therapist because, according to Silberschatz (2007), “...the client must perceive the therapist's acceptance and empathy, because if these therapist attitudes are not communicated in a manner that the client experiences or perceives them, then from the client's perspective they do not exist" (p. 265). This means that once PCA becomes the theoretic-methodological reference for the attendance in psychological duty, the perception of the client about the relationship conditions offered to the psychologist on duty is determinant for the success of the job. Having said that, we ask: what do clients that pass through an attendance of psychological duty based on person-centered therapy consider meaningful in the way that the psychologist on duty relates to them?

\section{Methodology}

Five clients from a service of psychological duty offered by a clinic-school from a Brazilian University were chosen to participate of the research. The choice was done randomly, and the only criterion was that they had to have from one to two attendances in the service, since the average number of attendance per person was 1.87. All the participants are female and between 30 - 45 years old.

We understand that the investigation now proposed is a research of nature, that is, one that is concentrated more in the nature of a phenomenon than in its length (Amatuzzi, 2003). So, when we asked about the meaningful aspects in a therapeutic relationship from the point of view of the attended clients, we inquired about the nature of this relationship according to a given perspective (in the case in point, the client's). It is possible to state as well that this is a qualitative research, once that, according to Andrade and Holanda (2010), this kind of investigation is concerned to the description of processes, valuing the particularities of a specific situation.

Martins and Bicudo (1989) clarify about the analysis developed in the qualitative research, stating that it is:

...an analysis that extends itself from what man is in his positivity (living, speaking, working, getting old and dying) to what enables this very man to know (or try to) what life is, in what the essence of work and laws consist of, in what ways he enables himself or becomes capable of speaking (p. 43).

This way, in the qualitative researches, the researcher investigates the phenomenon the way it is lived by the person, aiming to unravel its experiencing process. Objectively, this way, find the meaning that he attributes to his experience through the understanding of the subject.

In this sense, as an instrument that provided us with the necessary data for the proposed investigation, semi-structured interviews were done-a kind of interaction in which the researcher chooses a triggering question. According to Moreira (2004), the aim of this kind of question is “(...) essentially the meaning of the lived 
experienced to be researched” (p. 450).

The intention of the interview was to contemplate meaningful elements of the meeting between client and the Rogerian psychologist on duty. Due to this, we opted to do the interviews right after the end of the sessions, since that, according to Amatuzzi (2001), this gap allows the interviewee to be surrounded by the heat of the relationship. It is worth mentioning that the interviewer was concerned about in his interaction with the interview collaborator to “...remain active, present as an interlocutor who requests and shelters and also asking the person to return to her concrete experience when she wondered off to giving her opinion or theory” (Amatuzzi, 2003: p. 21). This way, the interaction between researcher and collaborator had the element of the concern of the first to show the latter his understanding about what was said, in a constant exercise of empathy (Rogers, 1975).

For the purpose of analysis, it was decided to carry out the research with a phenomenological methodology which, according to Amatuzzi (2009), aims to a return to the things themselves, so that the approach to the phenomena could be done from a non-natural attitude-the phenomenological attitude. With this focus, "the interest of the investigation is to "capture the lived world that is not necessarily known beforehand, but that in the act of the personal relationship, given the opportunity to express, is adopted" (Andrade \& Holanda, 2010: p. 264).

Andrade and Holanda (2010) postulate also that the adjusting of this method in researches aims to ascertain “...the subject's lived world, with the aim to investigate the sense or the meaning of living to the person in a given situation, with the objective of seeking the essential or invariant structure of the phenomenon” (p. 264). This way, the senses were the ones that clients attended by a duty service attributed to the qualities of the relationship with the psychologist on duty of person-centered approach, which guided the analysis done in this research.

As steps to the realization of the data analysis, Van der Leeuw's propose was adopted. It postulates the need for a reconstruction of the experience for the elaboration of signification of the phenomenon to be reported. The constants vigilance and questioning about the presuppositions that come with the phenomenological method aim the act of understanding per se, so that the "...chaotic reality, still, becomes a communication brought to our knowledge, a revelation" (Van der Leeuw, 1933/2009: p. 182). It means that the interviews, initially chaotic, started revealing a meaning to be understood and reported by us. Thus, after the contact with the total of interviews done, the initial concern was to describe the meaning of what had been said during the interaction, without any concern with theoretic a prioris or interpretation.

Next, happened what Van der Leeuw (1933/2009) calls “elucidation”, “...a clarification of what is seen [so that] we can gather what is mutual, separate what is not from the same nature" (p. 182). Thus, it was through the gathering between connections of meaning that are characteristic of the phenomenon itself that its comprehension could be reached, that is, an order through the approximation of the different forms the phenomenon presented itself. In the case proposed, what had been the most meaningful in the therapeutic relationship of a psychology duty service from the point of view of the clients attended in this service.

Thus, we could reach six categories that expressed the meanings present in the interviews: feel heard; interest from the psychologist on duty; feel welcome; confidence; unlimited time; self-knowledge.

\section{Results and Discussion}

The category "feel heard" is defined by the perception of the interviewed clients that hearing is endowed of value when it meets the Rogerian psychologist on duty. This hearing flows through a determined way of relating to the other, as it can be perceived in the speech of one of the interviewees:

I realize that she hears me and pays attention to what I'm saying. We are used to speaking with people from the outside ... it's as if they are not listening to you, but desiring you to leave them shortly ... her behavior, really professional, there really listening to me, giving me attention. She is not wishing me to leave soon. So this called my attention (C4).

The listening of the psychologist on duty is clearly described by the client. It is a listening that pays attention, so, it does not only mean decoding the words pronounced, but getting involved with them, recognizing a value to them and giving an answer based on this involvement. There is a parameter traced by the client that the listening that is offered to her is different from the one that is commonly found in her daily life. It is in this sense that Amatuzzi (1990) defines what means to hear in the Rogerian referential.

Still according to the author, a word “...heard means to be entirely pronounced. Without this, despite its ger- 
minal presence, it remains, in a certain way, unsaid” (Amatuzzi, 1990: p. 88). As the client report says, the entire pronouncing of the word is updated in a context of the genuinely interested relationship (Rogers, 1967/1976).

The listening offered at the psychological duty works as a way of guiding, as it can be seen below, or organizing an experience that needs to be said, to be put out, because, on the contrary, it becomes tumultuated. Mahfoud (1999), when describing an experience of psychological duty in a school, states that the professional in the kind of service now described “....is not there trying to solve any problem, but tries to be present welcoming the person and listening to them actively ...the professional tries to be centered in the person more than in the problem" (p. 53). This can be confirmed in the excerpt from C5:

It's only the fact that ...I was in need of spitting it out, unloading, things that happen in our lives and start disturbing, it goes, goes, and it gets to a point that it becomes very terrible for you, so, only the fact that she listens to me, was indeed very important. And beyond her listening to me, she guided me, listened to me, listened to me (C5).

The curious in this situation is that the guiding is not attached to an idea of instruction. That is, what "guides" the person are not directives given by the psychologist on duty, but the format of the relationship established between the person who seeks for help and the psychologist on duty, who sees in the acknowledgement of his ignorance the place of his wisdom (Vieira, 2009).

Listening and response are deeply connected. According to Amatuzzi (2010), true communication only happens when the said and the unsaid are heard, what is implicit in the other's discourse and when it is responded. Respond, in this sense, is not to guide or advise, but be present with the client, be genuinely in the communication. This skill only becomes feasible in an interpersonal relationship that happens from the comprehension and participation of the therapist as for the meaning that the client attributes to what he/she says (Amatuzzi, 2010). This aspect is also noticed by Myers (2000), who says: “...this sensing and understanding of the client's world relies on the therapist's capacity to listen to the client's experience and to respond to what is being heard" (p. 151). To Elliot, Bhoart, Watson and Greenberg (2011), the empathetic ability from the therapist makes it easier for the client to explore his/her experiences, as well as assess his/her feelings, values and goals.

Myers (2000) affirms that, when clients feel listened to in the context of the psychotherapy, they increase the exploration of their own experiences. The aforementioned author highlights "...the interactional nature of the therapeutic process and of the ways in which clients can move further and deeper into their own experience when they feel that they are being heard” (p. 161). This way, as the client feels himself/herself listened to, he/she becomes more empathetic with himself/herself. It is worth mentioning that, even in a context that is distinct from the psychotherapy, such as the psychological duty one, which in many times ends up being a one-onlysession event; this aspect is jutted out as meaningful by the attended clients. The experience of feeling heard, therefore, may not be attached to the variable of the length of the relationship between therapist and client.

Still under this same category, another interviewee said: "She did not judge. She kept on listening all the time" (C1). It is possible to notice, in this account, that listening and judging are distinct attitudes from the psychologist on duty. Feeling heard all the time, for her, implies in not feeling judged, that is, accepted. In the theoretical scope of PCA, this means that the psychologist on duty gives himself the challenge of accepting positively and unconditionally the person of the client, which is not only by assuming a position of not judging the client, but also acting towards the idea that, whatever are the feelings expressed in the relationship, they are worthy of value (Rogers, 1957/1992). Therefore, far from a neutral or indifferent behavior, the psychologist on duty places himself as a person who not only acknowledges, but who also values the alterity of the client.

When investigating the meaning of genuinity from the point of view of the client in psychotherapy, Schnellbacher and Leijssen (2009) point out that in all the interviews they did “...the clients experienced the therapist's attitude of acceptance as the most helpful or an important therapeutic process” (p. 216). Even if in the research herein reported we are not dealing with psychotherapy, nor interested in what attitude is the most important, the alluded investigation dialogues with us as the interest of the psychologist on duty is perceived by the client as an experience of acceptance by the other through authentic listening.

According to Rogers, listening someone is much more than listening to their words, it is to be able to understand a deeper meaning: it is to "hear the words, the thoughts, the feeling tones, the personal meaning, even the meaning that is below the conscious intent of the speaker” (Rogers, 1980: p. 8).

A characteristic of this listening, to Mahfoud (1999) is a genuine interest from the psychologist on duty in the person of the client. In the interviews, the clients reported perceiving this interest, building the category "inter- 
est from the psychologist on duty", illustrated by the speech: "I was able to feel comfortable. For her self, who I saw that had all the affection and the interest in helping me that moment (C1)".

As it is possible to see in the excerpt above, there is an open space for the exploration of the client's experience from a genuine interest from the psychologist on duty, which is perceived by the client. An interest that is translated by the word attention, that is, the client is attentive to the attention that is given by the psychologist on duty. It is in this sense that Cury and Ramos (2009) identify as a fundamental characteristic the availability of the psychologist on duty to "....welcome the emotional demand from the other through qualified listening and facilitating affective attitudes” (p. 139). The hope is that such behavior from the therapist favors the client's autonomy.

Schnellbacher and Leijssen (2009) define the therapist's genuinity from: his self-awareness; his presence in the here-and-now of the relationship, getting involved with the client's history through his self-presence and his self-disclosure. This way, the aforementioned authors think genuinity as “...an inner attitude, a relational experience, and a dynamic process between client and therapist” (p. 208). On the investigation now being discussed, the last two aspects are the ones that gain prominence in the perception of the client, so that it is possible to talk about experience of the genuinity of the other as a relevant condition for clients who pass through this kind of attendance. Rogers (1967/1976) points out as fundamental in the therapeutic relationship, the quality of the personal meeting, which surpasses the range of the specialist and the client, and contributes to the possibility of experiences of a larger personal growth. The psychologist on duty centered on the person, and who's attentive to the expression of the client, enables them to express their experiences and, thus, allows him/her to accept them too. Accepting their own experiences allow the clients the abandoning of outside evaluation criteria and take their own experiences as a reference to their actions (Rogers, 1959/1989; Cury \& Ramos, 2009), as, for instance, we can see in the client's speech ahead:

Her posture, the way she looks at me, because when I arrived here I didn't even know how to start talking. (...) the first contact with her gave me freedom enough for me to know at that moment where I should start from, the starting line for me to understand (C4).

As we can see above, the interest from the psychologist on duty evokes a sensation of freedom in the client, which, by the way, according to the aforementioned excerpt, is pointed out by the client as the starting point of a process. This liberty is triggered, then, by the perception, from the client, of a genuine interest coming from the psychologist on duty. To Cury and Ramos (2009), the relationship that is genuine and poses no threat “...makes it possible the triggering off of a therapeutic relationship potentially positive” (p. 139). This verification is confirmed by the researches by Perches (2009) and Mozena (2009).

Bohart and Byok (2005) name the interested we mentioned as presence. The mentioned authors analyzed three interviews done by Rogers and noticed that even more important than the therapist's specific techniques, "It was the constancy of caring that mattered" (p. 202). Rogers (1986/1989) was able to identify the genuinely interested presence of the therapist as a powerful tool in a relationship effectively of help.

To Rogers (1959/1989), a therapeutic relationship based on an environment of acceptance, empathy and interest from the therapist in relation to the client, enables the latter to talk about their own experience taking only themselves as reference. This way, the client may tact, recognize, state or deny their own experiences, without moral condemnation.

The client's speech, however, takes us to an idea that is slightly different from Roger's, which believes that the client himself is the starting point to taking a stand before his own experiences (Rogers, 1959/1989). What is possible to perceive is that the starting point is the relationship with the other, once the feeling of disorientation for which the client was passing was only overcome as the relationship with the psychologist on duty was established in a significative way.

Possibly due to monadological characteristics in his thoughts (Castelo Branco, 2012), Rogers does not perceives himself as a dimension of alterity present in the question that, from what is possible to realize, it is not the person himself/herself that gives a new direction for the matter, but the open and interested relationship that the psychologist on duty develops with him/her. It is in this same sense that, referring to the relationship established in psychotherapy, Bohart and Byock (2005) state that in the therapeutic attendance that uses the referential centered on the person, there are two people working on the same level, so that it's not only the actions of the therapist that fall upon the client, as well as the opposite, too.

The question of alterity in the Rogerian thought has been the target of many studies (Schmid, 1998, 2008; Vieira \& Freire, 2006, 2012; Vieira \& Pinheiro, 2013), happening to be crucial in the understanding of works 
that take this theory as their parameter. Mahfoud (2013) states that contemporaneity is marked by an excess of individualism and a distancing from the experience itself and that a relationship in which the psychologist on duty shows himself/herself to be someone willing to take part in the client's experiences, may help to handle in this context. In the case of the psychological duty, in which the interaction between psychologist on duty and client is marked by a bet in the radical commitment of the relationship of one and the other, there is an urgent need for studies that can be dedicated to the dimension of the alterity present there.

Returning to the reflections about the perspectives of clients in relation to the psychological duty of Rogerian orientation, we can emphasize the category "feel welcome". The welcome felt by the clients made the relationship between psychologist on duty and client closer, and made it more comfortable, as it is possible to see as follows: "She allows us to put out ...to put out everything we are feeling. When we have to cry, in this case, when I have to cry. She lets me cry, she gives me freedom for me to express my feelings" (C4).

In the excerpt above, it is possible to highlight the welcome felt by the interviewed client. Even if the psychologist on duty does not say it openly, it is implicit in his/her attitudes that the client may express whatever she wants and whenever she wants, in a deep environment of security and welcoming (Kinget, 1967/1977). This feeling of freedom in the relationship is reached when a person feels accepted by the psychologist on duty that does not patronizes or judges, trusting in his/her potentialities (Rogers, 1957/1992).

Another client reports this perception of welcoming from the psychologist on duty: "I felt her very, like, welcoming, I felt welcomed by her and due to this relationship I felt very at ease to talk about things" (C1). The client clearly expresses the welcoming feeling and consequently, the will to talk about herself, about what she lives and feels. Thus, it is possible to perceive that it's not any speaking that comes with the welcoming in the relationship. Amatuzzi (1990), from Rogers (1980), calls the attention to what really means to listen to someone. The speech of the aforementioned client makes us think about what really means to speak in the context of the psychological duty. As Miranda and Freire (2012) define, it's about a double movement, in which the person is heard by the other, but who also listens to in a different way than he/she uses to do commonly. Something very close to what we have already pointed out when we speak, from Myers (2000), that, when feeling heard by the psychologist on duty, the client starts to explore more deeply his/her experience.

This way, the client, when experimenting this welcome given by the relationship between psychologist on duty and client, felt more confident to explore freely and naturally her experiences and keep opened to them. Cury and Ramos (2009) corroborate with this point of view when developing a capacity to listen to in a relationship as proposed by the Person-centered Approach, the client “...is able to recognize and identify her own feelings, discriminating more clearly the issues lived and being able to explore more widely the problematic involved" (p. 139). Beyond that, it is observed that the implications of this welcome, of the interest of the psychologist on duty and his/her empathetic listening provided a well-being to the client that transcended the meeting's moment, as mentioned in the account that follows:

I found, like, her attitude, her behavior, a very good one. I felt welcome and all. So much that I felt an urge to come here only to say to her: "Look, stay well the whole week". And I said to her. Because I wanted her to know how I had felt the whole week (C1).

It is possible to see that the first meeting unfolded beyond the attendance, considering that the client spent the week well and returned to report that to the psychologist on duty. That is, the contact established from empathetic attitudes, from an attentive listening and an environment of positive and unconditional regard from the psychologist on duty's side gave the client the feeling of reorganization.

As for what it means change in the psychological duty, Perches (2009) warns us that “...significative change refers to a change in the perception of the person and their resuming of their personal autonomy, since the meaningful speech of the client opens possibilities” (p. 129). This means that what is aimed is not only a change regarding specific situations only, but a new positioning of the client regarding his/her issues.

The welcome that the client found in this format of relationship and the well-being that was provided at the moment of her psychological urgency was essential for her good development and the lessening of her level of distress, as it is possible to see in the following speech:

So this is it, I'm happy, very happy. I hope the people who seek for this service feel like this, too, welcome. There are people who don't need medicine, they just need a listening ear, someone who listens to them and make the person feel at ease (C1). 
It is interesting to highlight that the characteristic of the relationship that becomes more visible in the client's speech is the welcoming. It's as if it worked as a key that opens to the experience. This "feel at ease" narrated by the client demonstrates that the interest and comprehension of the psychologist on duty in this meeting were perceived by the client. The facilitating environment of security and warmth from the psychologist on duty was felt and helped her to feel welcome, lessening any threat feeling and establishing a relationship of trust (Kinget, 1967/1977). This aspect can be also seen in the following speech from another client:

... sometimes.... you don't speak because you think people will criticize you, that people won't accept that what you do is... a reality that happens... and here, no, we can speak and not be ridiculized... and the person (the psychologist on duty) understands that... that situation happens with people (C2).

The client delineates a deep difference between the format of the relationship that she establishes with the psychologist on duty and those she has outside the therapeutic setting. This is not only about a content problem, but also one of form, since the client speaks through a strong feeling of being able to speak without any kind of moral tie that interdicts the experience exploration. Reflecting about the kind of relationship proposed by Rogers, Schmid (1998) defines it through the word encounter, which implies in involvement with the immediacy of the experience of the relationship; action and passivity, because there is a mutual affectation between psychologist and client; take love as the adequate communication.

It's worth mentioning that love, in this context, is about an opening to the other for beyond the dyad therapistclient because, according to Schmid (1998), “...it is especially in love that encounter transcends the duality, the couple, and opens us for a Third One; first we do not live in the world of the human being, but in the world of human beings" (p. 83). We think that it is in this sense that Rogers (1967/1976) defines the therapeutic relationship as a non-possessive love. Mahfoud (2013) corroborates with this point of view when he observes that to the psychologist on duty, it is necessary

...with their attention (before any explanation), his presence and interest to the other, to communicate that it is worth examining the experience, it is worth entering the pain, the contradiction, the fear ...so that it has the chance of repositioning, and one more chance of getting in touch with himself/herself (p. 42).

Another category may be perceived in the account of the client when it comes to the relationship with the psychologist on duty: "Confidence". It is possible to see this in the following excerpt: "Since the first contact I had with her... I already felt confidence. I felt confidence in her" (C4). The confidence expressed by the interviewees is centered on the figure of the therapist. Not only about a reliance acquired through the therapeutic relationship, from the contact with the psychologist on duty, but in the place of knowing that this psychologist on duty occupies, and is able to become manifest to the clients, as the excerpt below demonstrates: "It is the confidence it gives me because, in this case, here I can show my weaknesses and to another person, I can't. We are afraid of speaking, of showing ourselves to the other" (C4).

The relationship established in the psychological duty, therefore, happens to be the one that shows a distinct parameter. It's as if the client quickly understood that there is an invitation for her to be different than in her usual relationships, a place of no fear, where she can show who she really is. If Rogers (1961) identifies the process of going beyond the social masks as an expected result from psychotherapy, in a continuum that goes from the perceptual rigidity to an experiential fluidity in the therapeutic relationship, it is possible to say, in the context of the psychological duty and on the brevity of its meetings, that it is possible to think about similar effects. Narrating a research with clients from a service of psychological duty in a hospital, Perches (2009) identified a similar phenomenon about people assisted in a psychological duty: "the attitude of unconditional regard of psychological experience from the part of the psychologist (...) surprised their clients, because the first did not propose to change the representation the client presents about oneself, however, demanded a new affirmation of oneself" (p. 129).

Kinget (1967/1977), while dealing with the qualities of the atmosphere of the therapeutic relationship, states it is constituted of confidence and warmth. According to the author, confidence may come from an exterior dimension, through the institutional figure of the therapist, or internal, when the clients feels safe, his distress is lessened in the relationship with the therapist.

When the client demarcates the different place in the relationship with the psychologist on duty, she recognizes in the psychologist on duty an uncommon confidence. This idea meets the perspective defended by Bohart and Byock (2005), from whom, in psychotherapy, “...clients are active, constructive interpreters of the therapy 
situation. They do not merely respond in a lockstep fashion to individual therapist responses” (p. 190). On the psychological duty, such relationship is also valid, and from what it is possible to notice, relevant so that a aid relationship can be developed, because, as Mahfoud (2013) says, "it is necessary to enter effectively in the relationship, it is not possible to leave the client alone with his/her own experience, it is necessary to ...have the courage to enter the pain with him" (p. 42).

To Bohart and Byock (2005), this kind of confidence does not come from an effort from the therapist to make something happen. For them, the range of the psychotherapy must always be “...a place for providing people with a safe space where they can talk to another person who recognizes and tries to understand them primarily as persons and gives them room to think" (p. 209).

The freedom felt by the client may give him/her the space to a wider opening into the experience, with no fears of what make come from it. According to Myers (2000), "Trusting the therapist and feeling safe with him or her frees the client to look at personal experience" (p. 170). Also, according to the aforementioned author, "The fear of being too vulnerable, of being overwhelmed by one's own pain, dissipates" (p. 170). It is exactly about the vanishing of these fears that the accounts of the clients brings us to.

It is worth reminding that what sustains this kind of relationship is the basis of trust over which the therapeutic relationship centered on the person is, so that the psychologist/therapist on duty has it clear that patronizing attitudes damage the development of an autonomy process that can be triggered. Concerning this, Rogers (1986/1989) says, “....as a therapist, I want to make it possible for my client to move in her own way, and at her own pace, to the heart of her conflicts” (p. 151).

The length of the sessions of the duty was also perceived as an important constituting element of the relationship between psychologist on duty and client. This way, we highlight here the category "unlimited time". The duty service offered in the institution consisted of up to four meeting, depending on the client's need, with no limit of time per session. For the interviewees, the unlimited time is a positive characteristic, even because it deconstructs the idea that the current view that the psychologist is always worried about the session's time, as it becomes evident in the speech of a client:

When we arrive here with a professional, with whom I came to seek for help, and find someone with this availability, with no rush like in “Oh, I'll go away, because there's a lot of people waiting”, at least I didn't have such concern and I saw that she didn't, either. She said to me: "you can tell me, our goal here is listening" and she calmed me down all the time (C1).

The client points out the availability of the psychologist on duty that attended her. For her, knowing that she could talk for how long she thought she needed to was meaningful, without the preoccupation of someone else outside who might be waiting to be attended. What defines time in the proposal herein adopted is the relationship established between the psychologist on duty and the client, and according to the person attended, this factor was a tranquilizing one for the good course of the meetings.

It is important to clarify, however, that the duty service is structured in a way so that it may have this larger flexibility of time, what would be unlikely in other attendance formats, such as psychotherapy. Herein it does not fit, then, criticizing other models of psychological attendance, since each one has different functions, as well as positive and negative points, but thinking about the possible consequences of this characteristic for the development of the therapeutic relationship under this format.

In this sense, it is worth mentioning, the psychological duty is an emergency service, which possibilitates a prolonged attendance and does not require returning. Thus, the development of a relationship of trust between the psychologist on duty and the client must be potentized, both for a major availability of the therapist in dealing with the unexpected and putting into practice the facilitating attitudes, as for a session that accompanies the client's own time, leaving him with more freedom to work on his/her demand. As the following excerpts demonstrate: "Who somehow cares, because from what you tell, it's not like her idea is: "let's finish this, because I want to attend somebody else" (C4).

An appointment with a psychologist is very expensive for someone with a low income, like me. To get it through SUS ${ }^{1}$ or through a Medical Center, it is much more difficult because you are going to wait for some-

${ }^{1}$ SUS is an acronym for Sistema Único de Saúde (Unified Health System). This is an achievement of the Brazilian federal constitution of 1988 , according to which a citizen's right is an obligation of the State, so that the access is universal and free of charge. Its effectuation, in the users' routine, is still problematic and, therefore, a constant target of discussions from the most diverse segments from Brazilian society because, as it is possible to see in the client's account, even though universalized, sometimes the attendance does not take place with the celerity that some cases demand. For further information, it is recommended the reading of Brasil (2011). 
thing like three or four months so you can have an appointment of about 10 to 15 minutes most of the times, because there are so many people to be seen that the time between the sessions is very short, but not here, since the first time I came, in the first session, in the second, I talk for almost one hour, sometimes even more than one hour, so I consider this very important (C5).

... she said, like, it was for me to put everything out, to talk about what was distressing me, what was making me worried, and she made me feel at ease. "You may talk without worrying about time", do you get it? She made me feel very at ease (C1).

To Cury and Ramos (2009), temporality is lived subjectively by the attended people and, “despite the duty being characterized as one or two attendances, this shows to be enough most of the cases, so that new directions can be seen by the client”. It is exactly the subjective character of the experience of time that regulates the duration of the attendance.

Rogers and Wood (1974) warn that the Person-centered Approach does not aim to follow a technicist logic that presupposes velocity in the overcoming of complaints taken by the clients to the psychotherapists. Through what the speeches of the interviewed clients suggest, the duty model adopted in the context of this research may radicalize this idea by not establishing a pre-determined limit of time for the duration of the attendance.

Untying from limits of time for the meeting wit the client may be understood as a deepening of Wood's idea (1994/2008) about psychotherapy, according to which it is not the therapist "who creates the environment; it is him/her and the client and the situation that are the environment. The client and the therapist do not create a relationship; he/she and the client are the relationship” (p. 211). The psychological duty situates the length of the session in favor of the relationship, so that it is its development that defines the duration of such relationship.

Another useful idea in order to think about this question is presented by Bohart and Byork (2005), who state that in the relationship therapist and client act together. If, as Wood says in the excerpt above, therapist and client are the relationship, it is their interaction that will define when and in what terms the process will come to and end. Perches (2009) emphasizes the importance of reciprocity and mutuality in the therapeutic relationship, so that it is proposed “... a break with the mechanized discourse on the behalf of a relational model, which brings in itself a dimension of the listening act that provokes the contact with the other” (p. 130). This is, therefore, a relationship that takes itself as reference to define itself, including as for its temporality.

The last category to be analyzed is "Self-knowledge" and it can be perceived in the following excerpt:

He knows the evolution will be inside me, ... that the evolution is not in what he's going to say, that the solution is within myself, that he shows me the way to find the solution, do you understand? So I find this very important (C2).

As it can be noticed in the excerpt above, the client emphasizes a non-directing position from the psychologist on duty. Such position takes to a perception of oneself as the one in charge for the issue taken to the attendance. It is worth mentioning that "in charge" in this context means to be able to respond to one's own question, and taking a stand.

The role of the psychologist on duty guided by the Person-centered Approach is to provide the necessary conditions so that the client himself/herself perceives himself/herself to be inside a relationship, acknowledges his/her experience and take a stand before them, believing in his/her potential and not assuming patronizing attitudes (Rosenthal, 1999). When the psychologist on duty has this confidence and is able to demonstrate it in his/her attitudes, the client acknowledges it and trusts even more in him/herself.

In addition, many of the attended clients arrived at the duty service with the idea that the psychologist would suggest ways of acting, or would advise them in order to solve their complaints. Since the psychologist on duty did not assume such role, the client, little by little, understood that the referential for change was within herself, as it can be seen in the following:

One day I said to him that I thought I was going to arrive here and find finished answers, all I had to do was seek for self-help, or do this, do that, if this one doesn't work, try that one... But no, what he does is to allow us to know ourselves as we are and try to seek within ourselves the solution to our problems (C2).

According to what was said by the client, seeking for solutions to her problems passed through obtaining finished answers with a specialist. This was before the psychological duty. But from the relationship she developed with the psychologist on duty, however, knowing herself obtains the primacy and is attached to finding a 
solution that comes from within herself. It is in this sense that Cury and Ramos (2009) say:

...it seems to be of fundamental importance that the clients may acknowledge and accept that the role of the psychologist on duty is not to provide them finished answers, but else, to guide them so that they can actively seek for new ways of dealing with their miseries (p. 136).

For Amatuzzi (2010), the Person-centered Approach acts with the presupposition of the autonomy, that is, it believes in the human capacity to grow. There is a belief in the hypothesis that people have what it takes to develop, thus, the goal of the psychologist on duty is not to set goals or strategies to solve a complaint, but promoting a relationship in which this capacity may emerge from the person (Santos, 2004). It is in this sense that Schmid (2008) says that the Rogerian therapist is a specialist in not being a specialist.

Believing in the potential of the client and listening to him/her does not configure a passive attitude. On the contrary, there is an intense and constant active movement from the psychologist on duty towards better understanding and apprehension of the client's experience (Vieira \& Dos Anjos, 2013). The psychologist on duty guided by the Person-centered Approach assumes an empathetic and accepting attitude that are genuine, communicating the client, in a non-verbal form, the confidence they have in his capacity to update their experience. Kinget (1967/1977) states that the role of the therapist is to: “(...) communicate the client without instructing him/her about it, that the direction of the conversation is in their own hands; that it's about their ideas, their choices, their decisions are the ones that matter, that the therapist is only an assistant” (p. 91).

One of the interviewed participants mentioned how she perceives this trust coming from the psychologist on duty in not advising her and her understanding of the importance that this attitude assumes in their relationship, because the client starts to notice that he/she is able to decided what he/she wants to do about the demand that took him/her to the psychological duty:

A factor that I consider important as well is him not saying what we have to do, do you understand? ... If the person says what we are to do, what we have to do, in fact it's not even what has.... What will really be good for us. For instance, if he says something like: "so, you do this, this and that", actually, that may not even be good to me, or what I need to do, or what I really want (C2).

In this speech there is a movement done by the client of the duty: initially she believed she had to be advised by the psychologist on duty and, along the attendance, she acknowledges her autonomy. To Mahfoud (2013), "authentic listening is an invitation for the client to let resonates in him/herself so many experiences so that somehow be able to take care and respond to them" (p. 40). This same client names, in a later part of the interview, this unknown movement: "So, this has been good to me, because I cannot always want to find the other person the answer to all my conflicts, you see? I have to have a self-knowledge in order to find, then, this for me" (C2).

The client reports the impossibility of finding in the other the answers to questions that are hers. She acknowledges in herself the need to know herself in order to take a stand before her own conflicts. As we have discussed elsewhere, such acknowledgement does not take place as a robotic process, but it is doable from the moment a meaningful relationship such as the one found on the psychological duty takes place.

This bigger self-awareness, as reported, can be translated by what Rogers (1987/2004) calls "moments of movement". Moments of movement are moments of change that happen when a person participates of a relationship in the patterns of the therapeutic relationship proposed by PCA. Such change implies in a full acceptance of an experience only partially experienced in other moments.

To Rogers (1987/2004) therapy is composed of many moments movement, that is, moments in which the person is able to live his/her experience fully, is able to feel it organically, elaborate it and, mainly, accept it. In general, those are experiences that have already been previously lived, but that were never able to be fully accepted, as can be observed on the following account:

When I arrived here it was as if I had a puzzle with me, my problems all spread out. To a certain extent, the question she makes-in which she doesn't say anything, she goes like, she goes according to what we say, then she asks-it is as if she starts focusing all that. A problem of which you had a different view, it starts to make sense to you, that situation you are passing through. So this helps me this way. It is as if now I have some pieces of the puzzle and started putting them in their proper places (C4).

The fact that there are no finished answers from the psychologist on duty, according to the excerpt above, 
helps organizing an experience that is similar to a puzzle. Finding a place to pronounce a word fully (Amatuzzi, 2001) is, as the client says, to focus on an issue that seemed to be blurred. It is evident, also, the connection of self-knowledge to the comprehension developed in the relationship between the psychologist on duty and the client. It is in this sense that Wood (1994/2008: p. 206) states: “...it is not enough to simply try to understand the other's world, not even trying to feel what the client is feeling ...The client must also experience being understood".

One can notice, therefore, the perception of a client about the moment of movement in the duty, since that, for the client, her problems could be seen like a puzzle that she could not assemble, that is, experiences with which she could not deal with. On the other hand, as the relationship with the psychologist on duty happens, she starts to be able to entirely live those experiences and the puzzle with which she was often confronted, but could not resolve, started to be assembled, since she has a different attitude towards her demand.

By fully living her experience, as said previously, the client gets farther and farther from the expectations and judgments of others, taking herself as a reference point. It is a movement of return to oneself, which is only possible in a relationship of expression and acceptance, like the one offered in the duty:

He (the psychologist on duty) allows us, it seems, to get in touch with that reality that sometimes we didn't want to exist or didn't want to admit that exists, and suddenly we have this possibility of knowing that in fact we are that way, and this is it (C2).

As we can realize, the relationship offered by the psychologist on duty allows the contact with strange aspects of the experience and their consequent acceptance. More than the encounter with an essence, the being itself to which the excerpt above alludes to is about the fact that the client assumes him/herself as their own possibility before what seems to be the strangest for them (Vieira \& Pinheiro, 2013).

The psychological duty does not propose itself to be a finished process, in which the client reaches a full state of acceptance of his/her experiences and a full perception of him/herself. But from the interviews it is possible to perceive that it is a space in which a movement of change can be triggered, once the parameters for a relationship that favors the growth of those who seek help are well delimitated.

\section{Final Considerations}

It was possible for us, through a phenomenological analysis of the interviews, to follow the meanings of the experiences of the therapeutic relationships in the psychological duty service. The categories described, however shown separately for didactic reasons, provide us a path of a flux that cannot be understood in a fragmented way. As already mentioned by Bohart and Byock (2005), it is not with isolated answers that the client relates to, but with the totality of a relationship. In this sense, listening, welcoming, interest, confidence, time and self-knowledge only make sense in the context now discussed inside a totality called therapeutic relationship. This unfolds into important implications so that the psychological duty can be considered.

The first of them is that one cannot think about this kind of relationship as something that happens only from one side or the other. This means that the psychologist on duty causes nothing to the client if the latter does not engage into a relationship and take it as a reference for a change. As Bohart and Byock (2005) punctuate in relation to psychotherapy, the client uses elements from the interaction with the therapist as tools to trigger a change process. The relationship deserves to be better investigated, mainly in the specificities of what the psychological duty is constituted of.

Thus, a comparative study between psychological duty and psychotherapy, for instance, could provide better clues to the understanding of the matter. It is important to highlight that, from what is herein being discussed, such investigation could not analyze only the conditions that the psychologist on duty must establish for his/her relationship with the client, but he/she must focus on what happens with and between both in this process, since it is from there that changes are possible.

If, as we stated, there is a mutual incidence in the interactions therapist-client, in a way that the client is understood as an active being in the relationship, how does the contact with different stories may cause different kinds of interaction between therapist and client? Or would there be a universal form of being with the other during the duty? There are evidences that different stories take to diverse manners of feeling heard by the other (Myers, 2000; Silberschatz, 2007).

Another important issue to be discussed is that if there are so many successful duty experiences in places other 
than only in clinical psychology (Mahfoud, 1999; Tassinari et al., 2013), what spaces would there be for a dialogue between the psychological duty and the public policies, for instance (De Souza, De Barros Neta, \& Vieira, 2012; Vieira \& Boris, 2012). Due to the flexibility of the duty model, one may have to consider an application of the latter into the aforementioned context, but rather than an implication, that is, a way of adapting according to the demands and potentialities of where it happens, for beyond the ties of a traditional clinical model. Researches in this sense may show to be useful in the development of a psychological clinic model that dialogues with different contexts.

Finally, it was possible to verify that, even in such a brief though intense relationship, such as the one on a duty, it is possible for the client to realize the quality of the presence of the psychologist on duty. The relationship described by the interviewed clients places a very strong importance in aspects to which Rogers (1957/1992) already called the attention to more than 50 years ago. The unconditional positive regard, the empathy and genuinity, so propagated as the facilitating attitudes developed and investigated by Rogers throughout his life; seem to make sense only in a context in which there is a willingness for the encounter with the other, an opening dimension which founds all the relationship to be established in a model centered on the person.

This way, even though there are accusations that PCA has an individualistic subject model (Moreira, 2007), it was the intersubjective aspect of a non-possessive presence that became visible in all the categories analyzed by us. It is possible to highlight that the psychologist on duty centered on the person takes the opening as a premise perfectly understood by the clients that, from then on, quickly become a presence in the relationship and can be positioned before their experiences. As Rogers predicted in former writings (Rogers, 1957/1992, 1959/1989), there is a potentiality in the model proposed by the approach that he created which transcends psychotherapy and that may contribute, in many sectors, for people's growth.

\section{Acknowledgements}

Universidade Federal do Pará, Pró-Reitoria de Pesquisa e Pós-Graduação and Fundação de Amparo e Desenvolvimento à Pesquisa from the same University for the financing of the translation from the original Portuguese version to the English version.

\section{References}

Almeida, F. M. (2009). Plantão Psicológico: De um resgate histórico a uma abordagem biográfica. In J. O. Breschigliari, \& M. C. Rocha (Eds.), Serviço de aconselhamento psicológico: 40 anos de história (pp. 23-37). São Paulo: SAP/IPUSP.

Amatuzzi, M. M. (1990). O que é ouvir. Estudos de Psicologia (Campinas), 7, 86-97.

Amatuzzi, M. M. (2001). Por uma psicologia humana. Campinas: Alínea.

Amatuzzi, M. M. (2003). Pesquisa fenomenológica em psicologia. In M. A. T. Bruns, \& A. F. Holanda (Eds.), Psicologia e fenomenologia: reflexões e perspectivas (pp. 17-25). Campinas: Alínea.

Amatuzzi, M. M. (2009). Psicologia fenomenológica: Uma aproximação teórica humanista. Estudos de Psicologia (Campinas), 26, 93-100. http://dx.doi.org/10.1590/S0103-166X2009000100010

Amatuzzi, M. M. (2010). Rogers: Ética humanista e psicoterapia. Campinas: Alínea.

Andrade, C., \& Holanda, A. (2010). Apontamentos sobre pesquisa qualitativa e pesquisa empírico-fenomenológica. Estudos de Psicologia (Campinas), 27, 259-268. http://dx.doi.org/10.1590/S0103-166X2010000200013

Battaglia, M. L. (2009). Carl Rogers e a mediação de conflitos. In A. Bacellar (Eds.), A psicologia humanista na prática: Reflexões sobre a Abordagem Centrada na Pessoa (pp. 128-136). Florianópolis: Unisul.

Bohart, A. C., \& Byock, G. (2005). Experiencing Carl Rogers from the Client’s Point of View: A Vicarious Etnographic Investigation. The Humanistic Psychologist, 33, 187-212. http://dx.doi.org/10.1207/s15473333thp3303_2

Brasil (2011). Sistema Único de Saúde_Coleção Para Entender a Gestão do SUS_Vol. 1. Brasília: Sistema Único de Saúde/ Conselho Nacional de Secretários de Saúde. http://www.conass.org.br/bibliotecav3/pdfs/colecao2011/livro_1.pdf

Breschigliari, J. O., \&. Rocha, M. C. (2009). Serviço de aconselhamento psicológico: 40 anos de história. São Paulo: SAP/ IPUSP.

Castelo Branco, P. C. (2012). Revisão de aspectos monadológicos da teoria de Carl Rogers à luz da fenomenologia social. Revista do NUFEN, 4, 83-98.

http://pepsic.bvsalud.org/scielo.php?script=sci_arttext\&pid=S2175-25912012000200009\&lng=pt\&tlng=pt

Cury, V. E., \& Ramos, M. T. (2009). Plantão psicológico em clínica escola: Prática e pesquisa. In J. O. Breschigliari, \& M. C. 
Rocha (Eds.), Serviço de aconselhamento psicológico: 40 anos de história (pp. 133-142). São Paulo: SAP/IPUSP.

De Souza, B. N., \& De Souza, A. M. (2011). Plantão psicológico no Brasil (1997-2009): Saberes e práticas compartilhados. Estudos de Psicologia (Campinas), 28, 241-249. http://dx.doi.org/10.1590/S0103-166X2011000200011

De Souza, L. C., De Barros Neta, F. T., \& Vieira, E. M. (2012). Interface do plantão psicológico e as políticas de assistência social. Revista do NUFEN, 4, 71-82.

http://pepsic.bvsalud.org/scielo.php?script=sci_arttext\&pid=S2175-25912012000200008

Dutra, E. (2004). Considerações sobre as significações da psicologia clínica na contemporaneidade. Estudos de Psicologia (Natal), 9, 381-387. http://dx.doi.org/10.1590/S1413-294X2004000200021

Elliot, R., Watson, J. C., Bohart, A. C., \& Greenberg, L. S. (2011). Empathy. Psychotherapy, 48, 43-49. http://dx.doi.org/10.1037/a0022187

Justo, H. (2002). Abordagem centrada na pessoa: Consensos e dissensos. São Paulo: Vetor.

Kinget, G. M. (1977). A Atmosfera. In C. R. Rogers, \& G. M. Kinget (Eds.), Psicoterapia e relações humanas: Teoria e prática da terapia não-diretiva (pp. 73-100). Vol. 1, Belo Horizonte: Interlivros.

Kirschenbaum, H., \& Jourdan, A. (2005). The Current Status of Carl Rogers and the Person Centered Approach. Psychotherapy: Theory, Research, Practice, Training, 42, 37-51. http://dx.doi.org/10.1037/0033-3204.42.1.37

Mahfoud, M. (1987). A vivência de um desafio: Plantão psicológico. In R. L. Rosenberg (Ed.), Aconselhamento psicológico centrado na pessoa (pp. 75-83). São Paulo: EPU.

Mahfoud, M. (2013). Desafios sempre renovados: Plantão psicológico. In M. A. Tassinari, A. P. S. Cordeiro, \& W. T. Durange (Eds.), Revisitando o plantão psicológico centrado na pessoa (pp. 33-50). Curitiba: CRV.

Mahfoud, M. (Org.) (1999). Plantão psicológico: Novos horizontes. São Paulo, Brazil: Companhia Ilimitada.

Martins, J., \& Bicudo, M. A. V. (1989). A Pesquisa Qualitativa em Psicologia: Fundamentos e recursos básicos. São Paulo: Moraes/EDUC.

Miranda, C. S. N., \& Freire, J. C. (2012). A comunicação terapêutica na abordagem centrada na pessoa. Arquivos Brasileiros de Psicologia, 64, 78-94. http://pepsic.bvsalud.org/scielo.php?pid=S1809-52672012000100007\&script=sci arttext

Moreira, V (2009). Clínica humanista-fenomenológica: Estudos em psicoterapia e psicopatologia crítica. São Paulo: Anna Blume.

Moreira, V. (2004). O método fenomenológico de Merleau-Ponty como ferramenta crítica de pesquisa em psicopatologia. Psicologia: Reflexão e crítica, 17, 447-456. http://dx.doi.org/10.1590/S0102-79722004000300016

Moreira, V. (2007). De Carl Rogers a Merleau Ponty: A pessoa mundana em psicoterapia. São Paulo: Anna Blume.

Moreira, V. (2010). Revisitando as fases da abordagem centrada na pessoa. Estudos de Psicologia (Campinas), 27, 537-544. http://dx.doi.org/10.1590/S0103-166X2010000400011

Mozena, H. (2009). Plantão Psicológico: Estudo fenomenológico em um serviço de assistência judiciária. Masters’s Thesis. http://www.bibliotecadigital.puc-campinas.edu.br/tde_arquivos/6/TDE-2009-03-23T125647Z-1487/Publico/Helen\%20Mo zena.pdf

Myers, S. (2000). Empathic Listening: Reports on the Experience of Being Heard. Journal of Humanistic Psychology, 40, 148-173. http://dx.doi.org/10.1177/0022167800402004

Norcross, J. C. (2001). Purposes, Processes, and Products of the Task Force on Empirically Supported Therapy Relationships. Psychotherapy: Theory, Research, Practice, Training, 38, 345-356. http://dx.doi.org/10.1037/0033-3204.38.4.345

Perches, T. H. F. (2009). Plantão psicológico: O processo de mudança psicológica sob a perspectiva da psicologia humanista. Unpublished Doctoral Dissertation, Campinas: Pontifícia Universidade Católica de Campinas.

Rogers (1989). A Client-Centered/Person-Centered Approach to Therapy. In H. Kirschenbaum, \& V. L. Henderson (Eds.), The Carl Rogers Reader (pp. 135-152). Boston, MA: Houghton Mifflin.

Rogers, C. R. (1961). On Becoming a Person: A Therapist's View of Psychotherapy. Boston, MA: Houghton-Mifflin.

Rogers, C. R. (1975) Empathic: An Unappreciated Way of Being. The Counseling Psychologist, 5, 2-10. http://dx.doi.org/10.1177/001100007500500202

Rogers, C. R. (1976). Algumas lições de um estudo de psicoterapia com esquizofrênicos. In C. R. Rogers, \& B. Stevens (Eds.), De pessoa para pessoa: O problema de ser humano (pp. 211-224). São Paulo: Pioneira.

Rogers, C. R. (1980). Experiences in Communication. In C. R. Rogers (Ed.), A Way of Being (pp. 5-26). Boston, MA: Houghton Mifflin.

Rogers, C. R. (1989). A Theory of Therapy, Personality, and Interpersonal Relationships, as Developed in the Client-Centered Framework. In H. Kirschenbaum, \& V. L. Henderson (Eds.), The Carl Rogers Reader (pp. 236-257). Boston, MA: Houghton Mifflin. 
Rogers, C. R. (1992). The Necessary and Sufficient Conditions of Therapeutic Personality Change. Journal of Consulting and Clinical Psychology, 60, 827-832. http://dx.doi.org/10.1037/0022-006X.60.6.827

Rogers, C. R. (2001). Sobre o poder pessoal. São Paulo: Martins Fontes.

Rogers, C. R. (2004). Momentos de movimento. In A. M. Santos, C. R. Rogers, \& M. C. V. B. Bowen (Eds.), Quando fala o coração: A essência da psicoterapia centrada na pessoa (pp. 15-23). São Paulo: Vetor.

Rogers, C. R., \& Wood, J. K. (1974). Client-Centered Theory: Carl Rogers. In A. Burton (Ed.), Operational Theories of Personality (pp. 211-258). New York: Brunner/Mazel.

Rosenthal, R. W. (1999). Plantão psicológico no Instituto Sedes Sapientiae: Uma proposta de atendimento aberto à comunidade. In M. Mahfoud (Ed.), Plantão psicológico: Novos horizontes (pp. 15-28). São Paulo: Editora C. I.

Santos, A. M. (2004). Novos caminhos na abordagem centrada na pessoa. In A. M. Santos, C. R. Rogers, \& M. C. V. B. Bowen (Eds.), Quando fala o coração: A essência da psicoterapia centrada na pessoa (pp. 43-67). São Paulo: Vetor.

Schmid, P. (2008). Conocimiento o reconocimiento? La psicoterapia como “el arte de no saber”. Perspectivas de más desarrollos de un paradigma radicalmente nuevo. http://members.kabsi.at/pfs0/paper-pcep1-span.pdf.

Schmid, P. T. (1998). "Face to Face”-The Art of the Encounter. In B. Thorne, \& E. Lambers (Eds.), Person-Centered Therapy: A European Perspective (pp. 74-90). London: Sage.

Schnellbacher, J., \& Leijssen, M. (2009) The Significance of the Therapist Genuiness from the Client's Perspective. Journal of Humanistic Psychology, 49, 207-228. http://dx.doi.org/10.1177/0022167808323601

Silberschatz, G. (2007). Comments on "The Necessary and Suficiente Conditions of the Therapeutic Personality Change". Psychotherapy: Theory, Research, Practice and Training, 44, 265-267. http://dx.doi.org/10.1037/0033-3204.44.3.265

Tassinari, A., Cordeiro, A. P. S., \& Durange, W. T. (Eds.) (2013). Revisitando o plantão psicológico centrado na pessoa. Curitiba: CRV.

Van der Leeuw, G. (2009). A religião em sua essência e suas manifestações: Fenomenologia da religião, 1933, Epílogo. Revista da Abordagem Gestáltica, 15, 179-183. http://pepsic.bvsalud.org/scielo.php?pid=S1809-68672009000200014\&script=sci_arttext

Vieira, E. M. (2009). Sobre a proposta de conhecimento presente na teoria Rogeriana, ou da sabedoria residente na ignorância. Revista do NUFEN, 1, 4-19. http://pepsic.bvsalud.org/scielo.php?pid=S2175-25912009000200002\&script=sci arttext.

Vieira, E. M. (2012). Aprendizagem significativa na formação universitária: A experiência do plantão psicológico da UFPA. In F. C. S. Lemos, A. L. S. Silva, C. S. Santos, \& D. L. Silva (Eds.), Transversalizando no ensino, na pesquisa e na extensão (pp. 441-451). Curitiba: CRV.

Vieira, E. M., \& Boris, G. D. J. B. (2012). O plantão psicológico como possibilidade de interlocução da psicologia clínica com as políticas públicas. Estudos e Pesquisas em Psicologia (UERJ), 12, 883-896. http://pepsic.bvsalud.org/scielo.php?script=sci_arttext\&pid=S1808-42812012000300010\&lng=pt\&nrm=iso

Vieira, E. M., \& Dos Anjos, K. P. L. (2013). Tornar-se plantonista: O fluxo de atitudes facilitadoras a partir da experiência de plantonistas iniciantes. In M. A. Tassinari, A. P. S. Cordeiro, \& W. T. Durange (Eds.), Revisitando o plantão psicológico centrado na pessoa (pp. 101-124). Curitiba: CRV.

Vieira, E. M., \& Freire, J. C. (2006). Alteridade e psicologia humanista: Uma leitura ética da abordagem centrada na pessoa. Estudos de psicologia (Campinas), 23, 425-432. http://dx.doi.org/10.1590/S0103-166X2006000400010

Vieira, E. M., \& Freire, J. C. (2012). Psicopatologia e terapia centrada no cliente: Por uma clínica das paixões. Memorandum, 23, 57-69. http://www.fafich.ufmg.br/memorandum/a23/vieirafreire01/

Vieira, E. M., \& Pinheiro, F. P. H. A. (2013). Person Centered Psychotherapy: An Encounter with Oneself or a Confrontation with the Other? Estudos de Psicologia (Campinas), 30, 231-238. http://dx.doi.org/10.1590/S0103-166X2013000200009

Vieira, E. M., \& Ximenes, V. M. (2011). Reflexões sobre possíveis contribuições de Carl Rogers para a Psicologia Comunitária. In A. Pimental, \& V. Franco (Eds.), Diálogos dentro da Psicologia: contribuições da investigação luso-brasileira em psicologia social, clínica e educacional (pp. 301-310). Évora: Aloendro.

Wood, J. K. (2008). Da abordagem Centrada na Pessoa à Terapia Centrada no Cliente: Uma retrospectiva de 60 anos. In J. K. Wood., J. R. Doxsey, L. M. Assumpção, M. A. Tassinari, M. Japur, M. A. Serra, R. Wrona, S. R. Loureiro, \& V. E. Cury (Eds.), Abordagem centrada na pessoa (pp. 163-282). Vitória: EDUFES. 